\title{
THE IMPORTANCE OF SOCIALLY RESPONSIBLE MARKETING PRACTICES ON THE HEALTY FOOD MARKET FROM THE PERSPECTIVE OF STUDENTS
}

\author{
Ana Vržina \\ Mag. oec.; e-mail: avrzin02@live.efst.hr \\ Mario Pepur \\ PhD, Associate professor, University of Split, Faculty of Economics, Business and Tourism, Cvite Fiskovića 5, \\ 21000 Split, Croatia; e-mail: mpepur@efst.hr
}

\begin{abstract}
It is widely believed that young people are not overly concerned about their health or that they take excessive care of their eating habits. However, marketing experts see them as an extremely important and potentially large market, and consider all socially responsible business initiatives as long-term investments that will increase the value of the company. In the healthy food market, marketing practices are among the most important activities of socially responsible business. The purpose of this study is to explore the importance of different socially responsible marketing practices on the healthy food market. The questionnaire was administered to 519 students and the results were analysed using latent class analysis (LCA). Research results confirm the importance of understanding the influence of key demographic variables (gender and household income) on customers' perceptions of socially responsible marketing. An important limitation of the research is the number and selection of socially responsible marketing practices. There are only a few studies that segment the market based on socially responsible marketing practises. A suggestion for future research is to use longitudinal data with more marketing practices tested.
\end{abstract}

Key words: Corporate social responsibility (CSR), Socially responsible marketing (SRM), Healthy food market, Student population

\section{INTRODUCTION}

Marketing professionals are often criticized for the way they design and conduct business activities. They are often blamed for harming consumers and society with their activities. Many authors (Laczniak and Shultz, 2020; Čutura, 2018; Lončarić, 2009) have criticized Friedman's claim that the only social responsibility of business is to maximize its profits within the law, as a dubious and counter-productive notion. Lončarić (2009) claims that managers should make marketing 
decisions based on the principles of ethics and social responsibility, while Stanic et al. (2016) state that socially responsible business represents a business model and management style in which the profit is realized in a socially responsible manner. The discussion of ethical behavior through marketing activities leads to the definition of social responsibility of marketing. It involves marketing behavior that is not oriented exclusively towards achieving marketing goals, i.e. market, sales, and profit goals of economic entities, but the one that at the same time also seeks to protect and strengthen the interests of society (Previšić and Ozretić Došen, 2004). Consumers are becoming increasingly socially conscious when making their purchasing decisions, which provides an incentive for companies to integrate social responsibility into their product offerings (Prendergast and Tsang, 2019). Consumption practice shows that the market is the most efficient and effective judge of social values and through their own consumption individuals can influence social change.

In recent years, both in the world and in the Republic of Croatia, interest in healthy food has increased. The importance of healthy food is promoted through various campaigns and in the media, which greatly influences consumer preferences. The healthy food market includes natural and organic foods. In 2016, the global organic market ranged from $€ 3$ billion in Canada to $€ 38.9$ billion in the US. At the EU level, it was worth $€ 30.7$ billion with the highest consumption in Germany and France ( $€ 9.5$ and $€ 6.7$ billion respectively). In China, it amounted to $€ 5.9$ billion. The sales of organic products in the EU increased from $€ 20.8$ billion in 2012 to $€ 30.7$ billion in 2016 (European Parliament, 2019). Although Germany is the leading market for organic products, Switzerland and the Nordic countries boast the highest levels of per capita consumption. European consumers have a high level of awareness for organic products at $61 \%$, with a further $11 \%$ who are actively looking for such products. The places of purchase are mostly general retailers/stores or specialized organic retailers, while the appeal of different products differs between countries, e.g. the United Kingdom has the largest market for organic fish (http://www.statista.com). The EU's organic logo guarantees that EU rules are respected in production, and labelling is mandatory for pre-packaged food. For processed foods, the logo means that at least $95 \%$ of the ingredients are of organic origin.

The paper draws on an empirical study by Patino et al. (2014) on the importance of different marketing practices. Patino et al. (2014) examined the importance that consumers in the United States place on different socially responsible marketing practices, and researched whether the level of importance varies by race, gender and income. The subject of this research is the importance of socially responsible behaviour in the healthy food market. The aim of this paper is to explore the importance that customers attach to different types of socially responsible marketing practices.

Hur et al. (2015) claim that due to the growing interest in corporate social responsibility (CSR), many companies have been investing considerable effort to identify how consumer demographics relate to CSR. Despite that, Patino et al. (2014) notice that relatively less attention has been devoted to how demographic variables may influence the importance of different socially responsible marketing practices for consumers. Therefore, our aim is to analyze further the potential impact of two important socio-demographic variables, namely gender and income among student population. Rao and Tilt (2020) suggest that limited research has examined whether gender diversity has any influence on corporate social responsibility (CSR). Hur et al. (2015) argue that 
marketers are concerned about better segmenting their marketing activities and emphasize the importance of gender in the market segmentation process. They also point out that their findings imply that the effects of CSR perception are not equal across gender and suggest that academics and practitioners need to identify the effect of gender on CSR. Regarding household income, Carvalho et al. (2010) state that the influence of customer perception on company social behaviour differs across low and high-income customers. Cambra-Fierro et al. (2020) also confirm the importance and impact of consumer income in the context of CSR in emerging markets. Therefore, we have additionally tested whether there are statistically significant differences in perceptions of the importance of different socially responsible marketing practices depending on the respondents' gender and household income. If marketers are to create a better world through socially responsible marketing, they require a comprehensive roadmap of what that means and where it leads (Laczniak and Shultz, 2020).

The environmental business segment and the increasing attention paid to healthy food has prompted us to reconsider all aspects of doing business in the healthy food market. With the increased presence of various negativities such as obesity, pesticides, contaminated food, GMO food and various diseases, the market for healthy food has grown. In this paper, young people's perception of the importance of the ten observed socially responsible marketing practices in the healthy food market is observed.

\section{SOCIALLY RESPONSIBLE BUSINESS}

\section{1 The concept of social responsibility}

Corporate social responsibility (CSR) has a long history. Many scholars have proposed their own definitions that have developed, evolved and changed over time. However, although a unique definition does not exist, the essence of the concept is the same. Howard R. Bowen, who is considered the father of the term "Corporate Social Responsibility", offered one of the first definitions of this concept in 1953. His initial definition of CSR was: "Corporate social responsibility refers to the obligation of businessmen to pursue those policies, to make those decisions, or to follow those lines of action which are desirable in terms of objectives and values of our society".

Hopkins (2014) states that corporate social responsibility (CSR) is:

1. A process that is concerned with treating the stakeholders of a company or institution ethically or in a responsible manner. 'Ethically or responsible' means treating key stakeholders in a manner deemed acceptable according to international norms.

2. Social includes economic, financial and environmental responsibility. Stakeholders exist both within a firm or institution and outside.

3. The wider aim of social responsibility is to create higher and higher standards of sustainable. 
In addition to numerous authors, organizations have also defined CSR. For example, the European Commission (2011) puts forward a new definition of CSR as "the responsibility of enterprises for their impacts on society" with the aim of:

1. Maximising the creation of shared value for their owners/shareholders and for their other stakeholders and society at large;

2. Identifying, preventing and mitigating their possible adverse impacts.

Corporate social responsibility has an internal and an external dimension (Pavić-Rogošić, 2012). Internal dimensions of CSR refer to various activities within a company and include employees, areas of investment in human capital, health and safety at work, change management, lifelong learning and empowerment of employees, better flow of information within the company, and better balance between work, family, and leisure. Internal CSR may also include the position of women, criteria for their promotion, equal pay of men and women, dismissal of workers, job security and the like. External dimensions of CSR extend the socially responsible business into the local community and involve a wide range of stakeholders: business partners, suppliers, consumers, public administration, local associations, etc. Socially responsible business integrates companies in their local setting. Companies contribute to their communities by providing jobs, paying taxes, caring for the workers' health and the stability and prosperity of the community in which they operate. The knowledge and skills of the local working population and the reputation that the company has in the local setting are important to them. They are involved in various ways in the local community, caring for the environment, fighting against corruption through transparent business, employing people with special needs, collaborating with the community, sponsoring various sports and cultural clubs and events, donations to charity, etc.

Laczniak and Shultz (2020) claim that CSR is a broad umbrella term, which reflects collective social expectations for business. There are many published research on CSR in Human resources, CSR operations, CSR Finance etc. They state that socially responsible marketing (SRM) is part of the broader domain of corporate social responsibility. Laczniak and Shultz (2020) suggest a normative definition of socially responsible marketing (SRM) at the theoretical core of which is the social contract, implicit understanding between the members of society and business organizations (including marketers), and its three elements: corporate citizenship, stakeholder orientation, and social/environmental sustainability. This complete definition of SRM additionally incorporates distributive justice as an important ethical measure and constructive engagement as its pragmatic compass for keeping a SRM focus.

Rudawska (2013) explains the changing role of marketing activities toward social responsibility. SRM activities have the potential to create stronger relationships between firms and customers and are an important source of value for customers. She further states that recent researches have revealed that companies that are perceived by the public as adopting more SRM practices are more likely to perform financially better than those companies that do not.

The following table provides an overview of previous research and elaborates on various socially responsible marketing practices. 


\section{Table 1. Elaboration of previous research on socially responsible marketing}

\begin{abstract}
"Corporate social responsibility practices in India: a comparative study of MNCs and Indian companies"
\end{abstract}

Narwal, M., Singh, R., (2013)

"Blinds up or down? The influence of transparency, future orientation, and CSR on sustainable and responsible behavior"

Foscht T., Lin Y. and Eisingerich A. B. (2017)

"Socially responsible human resource practices: disclosures of the world's best multinational workplaces"

Frangieh C. G., Yaacoub H. K. (2018)

"Corporate social responsibility in food retailing"

Piacentini M., MacFadyen L. and Eadie D. (2000)
The paper explores different corporate social responsibility practices and compares Indian companies and multinational corporations (MNCs) operating in India. The results show that there are minor differences in CSR practices of Indian companies and MNCs. The conducted factor analysis for MNCs and Indian companies resulted in the extraction of four factors that represent CSR practices: environmental marketing, sustainable development, local community support, and transparency and accountability. The difference is empowerment as the fifth factor in MNCs.

The key role of business transparency in influencing sustainable and responsible user behavior is researched. Positive benefits of transparency vary depending on the future orientation of the company, corporate social responsibility (CSR) and the level of customer involvement. The results show that transparency has a direct and positive effect on customers' willingness to engage in sustainable and responsible consumption.
The authors encourage discussion of socially responsible practices implemented by the human resources departments of world's best MNCs. Socially responsible human resource management aims to improve various aspects of an employee's life and fulfill an employee's social and personal expectations. They highlighted two important socially responsible human resource practices: equal career development opportunities and the integration of work and family practice.

The motivation of food retailers to engage in socially responsible activities is investigated. The study sought to determine the scope of CSR activities and the company's motivation to operate. The authors found that the main motives for retailers to accept socially responsible business are space maximization, profitability, and customer pressures. Although some proactive companies recognized the benefits of being considered socially responsible, no company was driven primarily by philanthropic motives. 
"Role of CSR in the consumer decision making process - The case of India“

Sudeepta Pradhan (2016)

"CSR - consumption paradox: examination of UK apparel companies"

Mei Yu, Dongmei Cao (2018)
This study identified factors affecting a consumer's purchase intentions while purchasing goods from a socially responsible firm. In the Indian context, most respondents have confidence in CSR but price plays a highly crucial role. Most customers believe that the company should conduct responsible activities using its own resources rather than charging it from their customers.
The research relates to consumer behaviour in relation to the corporate social responsible practices of 21 popular clothing companies in the UK. The results show that there is no significant difference of pro-social consumption for any group according to gender, education, occupation or income. Public awareness of CSR is still relatively weak and there is no significant correlation between consumer awareness of CSR practices and actual shopping behaviour. Finally, most consumers pay more attention to prices and quality than CSR-related products and are therefore unwilling to sacrifice for pro-social products or brands.

Source: Authors' research

\section{RESEARCH MODEL}

\section{1 Sample description and research methods}

Empirical research was conducted among students of the University of Split during January and February 2020. For the purpose of the research, a survey questionnaire containing 32 questions was designed and administered via e-mail and social networks to include as many respondents as possible. The questionnaire consisted of three parts. The first part included demographic questions. The second part consisted of Likert-scale questions that included statements on the importance the respondents attach as customers to each of the socially responsible marketing practices when buying products in the healthy food market. The respondents had to specify their level of agreement on a five-point scale. In the third binary part (1/0) of the survey, the respondents answered whether the listed socially responsible marketing practices were important to them or not. A total of 519 questionnaires were administered, out of which 438 were fully filled out and processed. Latent cluster analysis, Mann - Whitney $U$ test and Kruskal - Wallis test were used to process the data. The statistical programs Mplus (version 7) and SPSS (version 23) were used to assist in data processing.

\section{2 Research results}

\section{2. 1 Descriptive analysis of collected data}

In this part of the paper, the respondents' general characteristics are presented. Most of the respondents were female students. Out of the total number of respondents, 308 (70.32\%) were female and 130 (29.68\%) were male. With regard to the constituents of the University of Split, the sample is dominated by the students of the Faculty of Economics as a total of 188 respondents 
(42.92\%) were the students at this Faculty. A total of 69 respondents (15.75\%) were the students at the Faculty of Electrical Engineering, Mechanical Engineering and Naval Architecture, followed by 59 or $13.47 \%$ respondents from the Faculty of Humanities and Social Sciences with. Another 32 respondents, or $7.31 \%$, attended the Faculty of Chemistry and Technology. Twenty-four respondents or $5.48 \%$ studied at the Faculty of Law. Thirteen respondents or $2.97 \%$ studied at the Faculty of Civil Engineering, Architecture and Geodesy, the Faculty of Medicine and the University Department of Professional Studies. Twelve respondents, i.e. $2.74 \%$ studied at the Faculty of Science. Two respondents studied at the Faculty of Kinesiology and two at the Academy of Arts, making $0.46 \%$ of the sample each. There was one respondent from the University Department of Forensic Sciences and one from the University Department of Health Studies, making each $0.23 \%$ of the sample.

According to their level of studies, 165 of the total number of surveyed students were at the undergraduate level of studies (37.7\%), followed by 217 respondents (49.5\%) at graduate studies, with least respondents at the postgraduate level, i.e. 56 of them (12.8\%). With regard to the total monthly household income, most respondents, i.e. 128 of them (28.1\%), had a monthly household income between HRK 6,000 and 10,000. Almost one quarter or $24.7 \%$, i.e. 108 of them, had a total monthly household income between HRK 10,000 and 15,000 . A total of 89 students ( $20.3 \%$ of the total number of respondents) stated they had the highest household income offered in this survey, that of more than HRK 15,000 . Then, 67 respondents, or $15.3 \%$, stated that their total monthly household income was HRK 4,000-6,000. Another 36 respondents or $8.2 \%$ of the total number of respondents had a total monthly household income between HRK 2,000 and 4,000. Finally, 15 respondents (3.42\%) indicated that they had the lowest household income offered in this survey (HRK 2,000).

\subsubsection{Latent cluster analysis}

Latent cluster analysis (LCA) of a binary variable was conducted using Mplus (version 7) to identify consumer segments in the student population with regard to the importance they attach to different socially responsible marketing practices.

Table 2. Diagnostic validity tests

\begin{tabular}{|c|c|c|c|c|c|c|c|}
\hline Models & $\begin{array}{c}\text { Estimated } \\
\text { parameters }\end{array}$ & $\chi 2$ & df & Sig. & AIC & BIC & Entropy \\
\hline 1 & 10 & 690.501 & 993 & $>0.1$ & 4462.084 & 4502.884 & 1 \\
\hline 2 & 21 & 596.689 & 1.002 & $>0.1$ & 3852.861 & 3938.539 & 0.842 \\
\hline 3 & 32 & 459.504 & 990 & $>0.1$ & 3747.440 & 3877.998 & 0.770 \\
\hline 4 & 43 & 403.946 & 979 & $>0.1$ & 3715.259 & 3890.696 & 0.768 \\
\hline 5 & 54 & 355.545 & 967 & $>0.1$ & 3699.733 & 3920.049 & 0.809 \\
\hline 6 & 65 & 326.513 & 956 & $>0.1$ & 3692.614 & 3957.809 & 0.789 \\
\hline
\end{tabular}


Diagnostic validity tests were conducted for models of different number of clusters to identify the optimal number of latent clusters (classes). Table 2 shows the validity statistics for the six models tested: chi-square test, Akaike information criterion (AIC), Bayesian information criterion (BIC), and entropy. The $\mathrm{AIC}$ is an estimator of out-of-sample prediction error and thus the relative quality of statistical models for a given data set. AIC and BIC estimate the relative balance between model suitability and parsimony, whereby lower values represent optimal balance and entropy values indicate the overall level of uncertainty in the latent class arrangement (higher values represent lower entropy level). While the chi-square ( $\chi 2)$ values decrease monotonically as the number of classes increases, the values of the information criteria as well as the entropy statistics suggest that the four-cluster model classifies consumers with least error. Although the Bayesian information criterion increases slightly compared to the three-cluster model, other indicators provides us with the conclusion that the optimal number of clusters in the model is four. The probability tests above $60 \%$ are diagonally visible in Table 3 .

Table 3. Probability tests

\begin{tabular}{|c|c|c|c|c|c|}
\hline Cluster & No & 1 & 2 & 3 & 4 \\
\hline 1 & 234 & $\mathbf{0 . 9 0 6}$ & 0.052 & 0.000 & 0.042 \\
\hline 2 & 98 & 0.090 & $\mathbf{0 . 7 9 8}$ & 0.020 & 0.091 \\
\hline 3 & 40 & 0.000 & 0.023 & $\mathbf{0 . 9 5 8}$ & 0.018 \\
\hline 4 & 66 & 0.036 & 0.083 & 0.029 & $\mathbf{0 . 8 5 1}$ \\
\hline
\end{tabular}

The statistical analysis produced four clusters of students: "fully committed" cluster of respondents, making up $53.5 \%$ of the sample, "the moderates", i.e. respondents who are moderately interested in CSR, making up $22.4 \%$ sample, while uninterested comprise $9.2 \%$ and the locals $14.9 \%$ of the sample.

Table 4. Four-latent model of social responsibility

\begin{tabular}{|l|c|c|c|c|}
\hline \multicolumn{1}{|c|}{ SOCIALLY RESPONSIBLE MARKETING PRACTICES } & $\begin{array}{c}\text { Fully } \\
\text { committed } \\
\text { to CSR }\end{array}$ & Moderates & $\begin{array}{c}\text { Uninterested } \\
\text { in CSR }\end{array}$ & Locals \\
\hline Spread, frequency & $53.50 \%$ & $22.40 \%$ & $9.20 \%$ & $14.90 \%$ \\
\hline $\begin{array}{l}\text { 1. The company does not discriminate in employment. } \\
\text { 2. The company ensures good working conditions to its } \\
\text { employees. }\end{array}$ & 0.95 & 0.86 & 0.28 & 0.51 \\
\hline 3. The company cooperates with local companies / farmers. & 0.92 & 0.00 & 0.34 & 0.82 \\
\hline 4. The company's business is environmentally friendly. & 0.98 & 0.83 & 0.13 & 0.84 \\
\hline 5. The company cares about its consumers (buyers). & 1.00 & 0.90 & 0.30 & 0.68 \\
\hline 6. The company sponsors events in the local community. & 0.75 & 0.03 & 0.18 & 0.61 \\
\hline
\end{tabular}


A. Vržina, M. Pepur: The importance of socially responsible marketing practices on the healty food... Zbornik Veleučilišta u Rijeci, Vol. 9 (2021), No. 1, pp. 211-226

\begin{tabular}{|l|c|c|c|c|}
\hline $\begin{array}{l}\text { 7. The company does not take advantage of vulnerable } \\
\text { groups such as low-income employees and / or helpless } \\
\text { employees. }\end{array}$ & 0.99 & 0.83 & 0.24 & 0.68 \\
\hline 8. The company's business does not harm animals. & 0.98 & 0.91 & 0.26 & 0.38 \\
\hline 9. The company donates to charity. & 0.89 & 0.27 & 0.03 & 0.53 \\
\hline $\begin{array}{l}\text { 10. The company also caters for the part of the market } \\
\text { made up of low-income consumers. }\end{array}$ & 0.96 & 0.57 & 0.09 & 0.61 \\
\hline
\end{tabular}

Source: Authors' research

Cluster 1 consists of 234 respondents who attach great importance to socially responsible marketing practices implemented by companies in the healthy food market. Almost all respondents stated that they attach great importance to nine out of ten tested marketing practices (Table 4), and especially to marketing activities related to companies providing good working conditions for their employees ( $100 \%$ of the respondents) and care about their consumers ( $100 \%$ of the respondents). The exception is the marketing activity "sponsoring events in the local community" that $75 \%$ of the respondents in this cluster find moderately important.

Cluster 2 consists of 98 respondents who are moderately interested in socially responsible marketing practices conducted by companies in the healthy food market. The respondents stated that the following marketing activities are extremely important to them: company ensures good working conditions to its employees (98\%), cares about its consumers (90\%) and does not harm animals (91\%). The respondents from this cluster stated that "sponsoring events in the local community" (3\%) and "donating to charity" (27\%) are not important socially responsible marketing practices. Other marketing practices are moderately important to them.

Cluster 3 consists of the respondents who are uninterested in socially responsible marketing practices. They classified all practices as not being important to them. However, even in this cluster there are hints of importance for some of the tested marketing practices namely: the company does not discriminate in employment ( $28 \%$ of the respondents), ensures good working conditions to its employees (34\%), cares about its consumers (30\%), does not take advantage of vulnerable groups such as low-income employees and / or helpless employees (24\%) and its business does not harm animals (26\%).

Cluster 4 is made up of the so-called "Locals" thus named because all local topics are moderately to extremely important to them. For $97 \%$ of respondents from this cluster, it is extremely important that the company cares about its local consumers. Socially responsible marketing practices are very important to them, in particular the one where "the company ensures good working conditions for its employees" (82\%) and the one where "the company cooperates with local companies / farmers" ( $84 \%$ of the respondents). They attach the least importance to marketing practice "the company's business does not harm animals" (38\%). 
A. Vržina, M. Pepur: The importance of socially responsible marketing practices on the healty food... Zbornik Veleučilišta u Rijeci, Vol. 9 (2021), No. 1, pp. 211-226

\subsubsection{Testing research hypotheses}

H1: There is a statistically significant difference in perceptions of the importance of different socially responsible marketing practices depending on the gender of the respondents

The nonparametric Mann-Whitney $U$ test was used to test the first hypothesis since it is a sequential measurement scale with two independent samples. Gender differences in the perception of the importance of different socially responsible marketing practices were tested. The data were processed by the computer program SPSS - version 23.

Table 5. Aggregate results of testing the gender difference and the difference with respect to the respondents' household income in the perception of the importance of ten socially responsible marketing practices

\begin{tabular}{|c|c|c|c|c|c|c|c|}
\hline SRM practices & Mann-Wh. U & Wilcox. W & Z & $\begin{array}{c}\text { Asy.Sig } \\
\text { (2-tailed) }\end{array}$ & $\begin{array}{l}\text { Chi- } \\
\text { Square }\end{array}$ & df & Asy.Sig. \\
\hline $\begin{array}{l}\text { B1. The company } \\
\text { does not } \\
\text { discriminate in } \\
\text { employment }\end{array}$ & 17784.000 & 26299.000 & -2.126 & .033 & 4.696 & 2 & .096 \\
\hline $\begin{array}{l}\text { B2. The company } \\
\text { ensures good } \\
\text { working conditions } \\
\text { to its employees }\end{array}$ & 17629.500 & 26144.500 & -2.578 & .010 & 5.280 & 2 & .071 \\
\hline $\begin{array}{l}\text { B3. The company } \\
\text { cooperates with } \\
\text { local companies / } \\
\text { farmers }\end{array}$ & 16270.500 & 24785.500 & -3.311 & .001 & .125 & 2 & .939 \\
\hline $\begin{array}{l}\text { B4. The company's } \\
\text { business is } \\
\text { environmentally } \\
\text { friendly }\end{array}$ & 15151.000 & 23666.000 & -4.384 & .000 & 2.742 & 2 & .254 \\
\hline $\begin{array}{l}\text { B5. The company } \\
\text { cares about its } \\
\text { consumers (buyers) }\end{array}$ & 16443.500 & 24958.500 & -3.537 & .000 & .729 & 2 & .694 \\
\hline $\begin{array}{l}\text { B6. The company } \\
\text { sponsors events in } \\
\text { the local community }\end{array}$ & 17840.000 & 26355.000 & -1.883 & .060 & 5.685 & 2 & .058 \\
\hline $\begin{array}{l}\text { B7. The company } \\
\text { does not take } \\
\text { advantage of } \\
\text { vulnerable groups } \\
\text { such as low-income } \\
\text { employees and/or } \\
\text { helpless employees }\end{array}$ & 15155.500 & 23670.500 & -4.845 & .000 & 3.132 & 2 & .209 \\
\hline
\end{tabular}


A. Vržina, M. Pepur: The importance of socially responsible marketing practices on the healty food... Zbornik Veleučilišta u Rijeci, Vol. 9 (2021), No. 1, pp. 211-226

\begin{tabular}{|l|llll|lll|}
\hline $\begin{array}{l}\text { B8. The company's } \\
\text { business does not } \\
\text { harm animals }\end{array}$ & 15135.000 & 23650.500 & -4.452 & .000 & 4.707 & 2 & .095 \\
\hline $\begin{array}{l}\text { B9. The company } \\
\text { donates to charity }\end{array}$ & 16254.500 & 24769.500 & -3.244 & .001 & 2.963 & 2 & .227 \\
\hline $\begin{array}{l}\text { B10. The company } \\
\text { also caters for the } \\
\text { part of the market } \\
\text { made up of low- } \\
\text { income consumers }\end{array}$ & 15520.000 & 24035.000 & -3.949 & .000 & 8.473 & 2 & .014 \\
\hline
\end{tabular}

Source: Authors' research

Mann-Whitney $U$ test results $(B 1: Z=-2.126, p=0.033 ; B 2: Z=-2.578, p=0.010 ; B 3: Z=-3.311, p=0.001$; $B 4: Z=-4.384, p=0.000 ; B 5: Z=-3,537, p=0.000 ; B 7: Z=-4.845, p=0.000 ; B 8: Z=-4.452, p=0,000 ; B 9$ : $Z=-3.244, p=0.001 ; B 10: Z=-3.949, p=0.000$;) show that at the $5 \%$ level of significance there is a statistically significant difference between men and women in the perception of importance of nine socially responsible marketing practices. In the remaining socially responsible marketing practice (B6: The company sponsors events in the local community, $Z=-1.883, p=0.060$ ) there is a no statistically significant difference with a significance level of $5 \%$. Based on the results of the nonparametric Mann-Whitney $U$ test, it can be concluded that the first research hypothesis is accepted and that there is a statistically significant difference between men and women in the perception of the importance of different socially responsible marketing practices in the healthy food market.

H2: There is a statistically significant difference in perceptions of the importance of different socially responsible marketing practices depending on the respondents' household income

The nonparametric Kruskal-Wallis test was used to test the second hypothesis since it is a sequential measurement scale with six independent samples. The difference with respect to the respondents' household income in the perception of the importance of different socially responsible marketing practices was tested. In table 5 , the test results $(B 10: x 2=8.473, p=0.014)$ show that, with a marginal significance of $5 \%$, there is a statistically significant difference in the perception of importance in only one observed socially responsible marketing practices with regard to the respondents' household income. For the remaining nine socially responsible marketing practices ( $B 1: x=4,696$, $p=0.096 ; B 2: x 2=5.280, p=0.071 ; B 3: x 2=0.125, p=0.939 ; B 4: x 2=2.742, p=0.254 ; B 5: x 2=0.729, p=0.694$; B6: $x 2=5.685, p=0.058 ; B 7: x 2=3.123, p=0.209 ; B 8: x 2=4.707, p=0.095 ; B 9: x 2=2.963, p=0.227$;), the test results show that there is no statistically significant difference in the perception of importance in relation to the household income. Based on the results of the nonparametric Kruskal-Wallis test, it can be concluded that the second research hypothesis is rejected since there is no statistically significant difference in the perception of the importance in nine out of ten observed socially responsible marketing practices with regard to the respondents' household income.

The study further investigated whether there are statistically significant differences in the perception of importance of the socially responsible marketing practices depending on the respondents' level of study. Since the intention of students after graduation is to find a job as soon as possible, in the 
research, emphasis was put on employment and working conditions. The nonparametric MannWhitney $U$ test was used because the students were divided into two independent samples: the undergraduate level of study (165 respondents) and a pooled group of respondents (273 respondents) consisting of graduate and postgraduate students, that are referred to as senior students.

Table 6. Test results of the difference in perception of the importance of two socially responsible marketing practices depending on the level of study

\begin{tabular}{|c|c|c|}
\hline Test statistic & $\begin{array}{c}\text { B1. The company does not } \\
\text { discriminate in employment }\end{array}$ & $\begin{array}{c}\text { B2. The company ensures good } \\
\text { working conditions to its employees }\end{array}$ \\
\hline Mann-Whitney U & 19901,000 & 20572,000 \\
Wilcoxon W & 57302,000 & 57973,000 \\
Z & $-2,350$ & $-1,983$ \\
Asy.Sig (2-tailed) &, 019 &, 047 \\
\hline \multicolumn{2}{|c|}{ Source: Authors' research } \\
\hline
\end{tabular}

The results of the Mann-Whitney test for both observed socially responsible marketing practices (B1: The company does not discriminate in employment, $\mathrm{Z}=-2.350, \mathrm{p}=0.019$; and $\mathrm{B} 2$ : The company ensures good working conditions to its employees, $Z=-1.983, p=0.047$ ) show that there is a statistically significant difference in the perception of importance among senior students compared to undergraduate students as the former attach more importance to the two practices than the latter.

\section{3 Research limitations}

The survey was conducted on a large number of respondents ( 438 of them), but if we take into account the size of the student population at the state level, as well as the total population buying in the healthy food market, the sample size in this survey is not entirely satisfactory. Further, the respondents were all from the same university. The obtained results are suitable for making indicative conclusions, while to create a complete picture it would be necessary to conduct research on a larger sample. An important limitation of the research is the fact that it was conducted at one point in time and, based on these results, no conclusions about the causality can be drawn.

Although the survey is anonymous, a social desirability response bias must not be overlooked. Another research limitation is related to a lack of previous similar research in Croatia that this research's results could be compared to. When developing the questionnaire for this research, the authors built on a research on the perceptions of the socially responsible marketing practices as seen by the the visitors of a festival in Baltimore, United States who singled out as the most important CSR practices. It should be pointed out that these visitors are different from people in Croatia, in cultural and developmental terms. The number of respondents in that study was very small (232 respondents) considering the total U.S. population. Therefore, an important research limitation is the number and selection of socially responsible marketing practices that may not be 
identical for EU and US countries. For example, in both surveys, business transparency was omitted as an important socially responsible marketing practice in the fight against corruption, which is extremely important for developing countries.

\section{DISCUSSION AND CONCLUSION}

Besides the fact that this empirical research is one of the first studies dealing with student consumers' perception of SRM practices in Croatia, this paper additionally enriches marketing literature and sheds light on whether gender diversity and household income influence SRM practices. Recent research shows that the field of CSR research is becoming broader and more complex, but this paper suggests that there is a need for more studies exploring SRM practices. From the management standpoint, companies are responsible for developing socially responsible marketing practices, whereas from the marketing theory standpoint customer is the primary stakeholder. Numerous justified criticisms on a global level and ever greater consumer awareness have forced marketers to creatively design and implement socially responsible business activities in order to strengthen and protect the society as a whole. Research results indicate that it is important to understand the impact that the key demographic variables, gender diversity and household income, have on customers' perceptions of socially responsible marketing practices in the healthy food market. Our findings empirically demonstrate that gender plays an important role in shaping the perception of student population for various socially responsible marketing practices, which is not the case for income.

The results of the latent class analysis (LCA) partially confirm the findings of Patino et al. (2014). The differences between Patino et al's sample and the one used in this research primarily arise from the age structure and cultural characteristics of the respondents. The four-cluster model obtained by LCA proved to be empirically more appropriate than the five-cluster model obtained in Patino et al's (2014) research in the US. The first two clusters, "Fully committed" and "Moderates" are almost identical in most of the marketing activities researched in both surveys. The remaining two clusters, "uninterested in CSR" and "locals", differ thematically from the two US clusters where the emphasis is on marketing practices of non-discrimination in recruiting and donating the people in need, and the last cluster is characterized by a complete lack of care for compassionate practices for the disadvantaged people and animals. In addition to the fact that marketers are constantly concerned about better market segmentation, our findings show that the differences between the four clusters of student population in how they view the company's efforts in socially responsible marketing as consumers are rather profound. Despite the fact that this research is limited to one demographic group, it is indicative that if marketers want to use their socially responsible actions as a market differentiator, their messages to target segments must be different, creative and very carefully planned.

Having processed the set hypotheses, the research was extended to include some additional variables that were supposed to strengthen the connection between the observed practices and the perceptions of the student population. Thus, it was further investigated whether there are statistically significant differences in the perception of importance in those practices that are closely related to employment and working conditions depending on the respondents' level of study. The results showed that there is a statistically significant difference in the perception of importance 


\section{A. Vržina, M. Pepur: The importance of socially responsible marketing practices on the healty food... Zbornik Veleučilišta u Rijeci, Vol. 9 (2021), No. 1, pp. 211-226}

among senior students compared to undergraduate students. The probable reason for this is the fact that senior students are closer to looking for and getting a job, so they are more sensitive to these practices carried out by business entities. Furthermore, Toker et al. (2016) claim that the attitudes of students as consumers towards socially responsible companies positively change if they have had even a minimal training in CSR, SRM or business ethics during their studies. In order to change the behavior of existing consumers and direct them towards a more socially responsible consumption in the future, it is suggested that companies develop joint educational programs with higher education institutions.

The aim of this research was to draw attention to the importance of conducting socially responsible business, which in the authors' opinion is not sufficiently represented in Croatia and in other emerging markets. We agree with the opinion that SRM cannot be imposed on companies, since it must be understood and accepted by them (Rudwanska, 2013). Practically, our findings will help marketers in designing their SRM practices to change perceptions among students, especially those students in the "uninterested" cluster. Marketing professionals need to think about the specifics of each market individually and the characteristics of the cluster when creating, communicating and implementing socially responsible marketing practices. Limitations of this study may serve as a potential starting point for future studies. First, future research should be conducted on a larger and more representative sample of the entire population. Second, given the unquestionable development of society over time, future research should be conducted as a longitudinal research with a number of tested marketing practices in order to be able to follow the course of development of socially responsible business. Third, future research should examine the effects of other demographics (e.g. age, education, employment) on socially responsible practices.

\section{REFERENCES}

Bowen, H. R. (1953) Social responsibilities of the businessman, New York: Harper \& Row.

Cambra-Fierro, J. J., Flores-Hernandez, J. A., Perez, L. (2020) “CSR and branding in emerging economies: The effect of incomes and education", Corporate Social Responsibility and Environmental Management, 27 (6), pp. 2765 - 2776. https://doi.org/10.1002/csr.2000

Carvalho, S. W., Sankar, S., de Oliveira Mota, M., Carniero de Lima, R. (2010) "Consumer reactions to CSR: a Brazilian perspective”, Journal of Business Ethics, 91, pp. 291 - 310. https://doi.org/10.1007/s10551-010-0620-0

Chattananon, A., Lawley, M., Supparerkchaisakul, N., Leelayouthayothin, L. (2008) "Impacts of a Thai cause-related marketing program on corporate image", International Journal of Emerging Markets, 3 (4), pp. 348 - 363. https:// doi.org/10.1108/17468800810906066

Čutura, M. (2018) “Marketing dionika: prema boljem razumijevanju društvene odgovornosti marketinga”, Ekonomska misao i praksa, 1, pp. 141-156. https://hrcak.srce.hr/202276

European Commission (2011) "A renewed EU strategy 2011-14 for Corporate Social Responsibility", Brussels. https:// eurlex.europa.eu/LexUriServ/LexUriServ.do?uri=COM:2011:0681:FIN:EN:PDF\#: :text=The\%20European\%20 Commission\%20has\%20previously,stakeholders\%20on\%20a\%20voluntary\%20basis\%E2\%80\%9D [January 21, 2021]

European Parliament (2018) Available at: http://www.europarl.europa.eu/news/hr/headlines/society/20180404ST O00909/eu-uvodi-stroza-pravila-za-trziste-ekoloske-hrane [September 21, 2020] 
Foscht, T., Lin, Y., Eisingerich, A. B. (2018) "Blinds up or down? The influence of transparency, and CSR on sustainable and responsible behaviour", European Journal of Marketing, 52 (3/4), pp. 476-498. https://doi.org/10.1108/EJM10-2016-0576

Frangieh, C. G., Yaacoub, H. K. (2018) "Socially responsible human resource practices: disclosures of the world's best multinational workplaces", Social Responsibility Journal, 15 (3), pp. 277 - 295. https://doi.org/10.1108/SRJ-11-20170226

Hopkins, M. (2014) "What is CSR all about", ASPIRARE, I (September 2014), pp. 1-21. https://www.researchgate.net/ publication/272832575_What_is_CSR_all_about [September 20, 2020]

Hur, W. M., Kim, H., Jang, J. H. (2015) "The Role of Gender Differences in the Impact of CSR Perceptions on Corporate Marketing Outcomes", Corporate Social Responsibility and Environmental Management, 23, pp. 345-357. https:// doi.org/10.1002/csr.1380

Laczniak, G., Shultz, C. (2020) "Toward a Doctrine of Socially Responsible Marketing (SRM): A Macro and NormativeEthical Perspective”, pp. 1-31. https://doi.org/10.1177/0276146720963682

Lončarić, D. (2009) "Socially responsible marketing decisions- scale development", Tržǐ̌te, XXI (1), pp. 7 - 23. https:// hrcak.srce.hr/53076

Narwal, M., Singh, R. (2013) "Corporate social responsibility practices in India: a comparative study of MNCs and Indian companies", Social Responsibility Journal, 9 (3), pp. 465 - 478. https://doi.org/10.1108/SRJ-11-2011-0100

Patino et al. (2014) "How important are different socially responsible marketing practices? An exploratory study of gender, race and income differences", Journal of Consumer Marketing, 31 (1), pp. 2 - 12. https://doi.org/10.1108/ JCM-10-2013-0733

Pavić - Rogošić, L. (2012) “Društveno odgovorno poslovanje”, Odraz, Zagreb, Retrieved from: http://www.odraz.hr/ media/21845/dop.pdf [February 17, 2020]

Piacentini, M., MacFadyen, L., Eadie, D. (2000) "Corporate social responsibility in food retailing", International Journal of Retail \& Distribution Management, 28 (11), pp. 459 - 469. https://doi.org/10.1108/ 09590550010356822

Pradhan, S. (2018) "Role of CSR in the consumer decision making process - The case of India", Social Responsibility Journal, 14 (1), pp. 138 - 158. https://doi.org/10.1108/SRJ-06-2016-0109

Prendergast, G. P., Tsang, Alex S. L. (2019) “Explaining socially responsible consumption”, Journal of Consumer Marketing, 36 (2), pp. 146 - 154. https://doi.org/10.1108/JCM-02-2018-2568

Previšić, J., Ozretić Došen, Đ. (2004) Marketing, Zagreb: Adverta.

Rao, K. K. and Tilt, C. (2020) "Gender and CSR decisions: perspectives from Australian boards", Meditari Accountancy Research. https://doi.org/10.1108/MEDAR-11-2019-0609

Rudawska, E. (2013) “Socially Responsible Marketing in Creating Value for Customers in the Polish Market", International Business \& Management, 29, pp. 73 - 94. https://doi.org/10.1108/S1876-066X(2013) 0000029009

Shankar, A., Yadav, R. (2020) "Understanding the impact of CSR domain on brand relationship quality", Marketing intelligence \& planning, ahead of print. https://doi.org/10.1108/MIP-10-2020-0442

Stanić, M., Kovačević, A. K., Blažević, I. (2016) “Corporate social responsibility on the example of selected companies”, 5th International Scientific Symposium on Economy of Eastern Croatia - Vision and Development, Osijek, Ekonomski fakultet u Osijeku, pp. 826 - 832. https://apps.webofknowledge. com/full_record.do?product=WOS\&searchmo de $=$ GeneralSearch\&qid $=51 \&$ SID $=$ D5eGbZyuFLcHR8GuPa8\&page $=4 \&$ doc $=34$

Tian, Z., Wang, R., Yang, W. (2011) "Consumer responses to corporate social responsibility (CSR) in China", Journal of Business Ethics, 101, pp. 197-212. https://doi.org/10.1007/s10551-010-0716-6

Toker, H., Turker, D., Altuntas, C. (2016) "Social responsibility education in Turkey", In: Springer International Publishing, Social Responsibility Education Across Europe: A Comparative Approach, Cham: Springer.

Yu, M., Cao, D., Tan, J. Y. (2018) “CSR - consumption paradox: examination of UK apparel companies", Journal of Fashion Marketing and Management, 23 (1), pp. 124 - 137. https://doi.org/10.1108/JFMM-02-2018-0021 
Prethodno priopćenje

https://doi.org/10.31784/zvr.9.1.13

Datum primitka rada: 23. 11. 2020.

Datum prihvaćanja rada: 10. 2. 2021.

\title{
VAŽNOST DRUŠTVENO ODGOVORNIH MARKETINŠKIH PRAKSI NA TRŽIŠTU ZDRAVE HRANE IZ PERSPEKTIVE STUDENATA
}

\author{
Ana Vržina \\ Mag. oec; e-mail: avrzin02@live.efst.hr \\ Mario Pepur \\ Dr. sc., izvanredni profesor, Ekonomski fakultet Split, Cvite Fiskovića 5, 21000 Split, Hrvatska; \\ e-mail:mpepur@efst.hr
}

\section{SAŽETAK}

Uvriježeno je mišljenje kako mladi ljudi nisu pretjerano zabrinutiza zdravlje niti vode pretjerano računa o prehrambenim navikama. Međutim, marketinški stručnjaci na njih gledaju kao na iznimno bitno i potencijalno veliko tržište te sve inicijative društveno odgovornog poslovanja smatraju dugoročnim ulaganjima koja će povećati vrijednost poduzeća. Na tržištu zdrave hrane među najvažnijim aktivnostima društveno odgovornog poslovanja nalaze se upravo marketinške prakse. Surha studije je istražiti koliko su važne različite društveno odgovorne marketinške prakse na tržištu zdrave hrane. Istraživanje je provedeno na uzorku od 519 studenata, a rezultati su obrađeni pomoću latentne klaster analize (LCA). Rezultati istraživanja pokazali su značaj razumijevanja ključnih demografskih varijabli (spol i prihod kućanstva) na oblikovanje percepcije kupaca o društveno odgovornom marketingu. Bitno ograničenje istraživanja je broj i odabir društveno odgovornih marketinških praksi. Postoji svega nekoliko istraživanja koja segmentiraju tržište u odnosu na društveno odgovorne marketinške prakse. Buduća istraživanja trebala bi biti longitudinalna s više testiranih marketinških praksi.

Ključne riječi: društveno odgovorno poslovanje, društveno odgovorni marketing, tržište zdrave hrane, studentska populacija 